\title{
The Effect of Methyl Jasmonate on Ethylene Production, ACC Oxidase Activity and Carbon Dioxide Evolution in the Yellowish-Tangerine Tomato Fruits (Lycopersicon esculentum Mill.)
}

\author{
JANUSZ CZAPSKI ${ }^{1}$, ARTUR MISZCZAK ${ }^{2}$, MARIAN SANIEWSKI ${ }^{2}$ \\ ${ }^{1}$ Research Institute of Vegetable Crops, Konstytucji 3 Maja 1/3, 96-100 Skierniewice, Poland and \\ ${ }^{2}$ Research Institute of Pomology and Floriculture, Pomologiczna 18, 96-100 Skierniewice, Poland
}

(Received: September 18, 1996)

A b s tract

\begin{abstract}
The yellowish-tangerine tomato (cv. Bursztyn) in the green, light yellow and yellow stages of ripening were treated with $0.1 \%$ and $1.0 \%$ of methyl jasmonate (JA-Me) in lanolin paste and kept for several days and then they were evaluated for production of ethylene, ACC oxidase activity and $\mathrm{CO}_{2}$ evolution. Production of endogenous ethylene in mature green fruits was low and increased during ripening. JA-Me stimulated ethylene production and ACC oxidase activity in all investigated stages of fruit ripening. Slices excised from mature green fruits produced highest amount of carbon dioxide as compared to more advanced stages of ripening. JA-Me in $0.1 \%$ and $1.0 \%$ concentrations increased significantly $\mathrm{CO}_{2}$ evolution in green fruits, while in light yellow and yellow fruits only higher concentration of JA-Me stimulated carbon dioxide production.
\end{abstract}

Key words: Lycopersicon esculentum, yellowish-tangerine tomato fruit, methyl jasmonate, ethylene production, $\mathrm{ACC}$ oxidase, $\mathrm{CO}_{2}$ evolution.

\section{INTRODUCTION}

Methyl jasmonate (JA-Me) and jasmonic acid are endogenous compounds which are widespread in plants and show many physiological activities (M e y e $\mathrm{r}$ et al., 1984). Some physiological processes during the ripening of tomato fruits are affected by methyl jasmonate. It has been found that JA-Me inhibits lycopene and stimulates $\beta$-carotene accumulation ( $\mathrm{S}$ a $\mathrm{n}$ i e w s k i and $\mathrm{C} \mathrm{z}$ a p s k i, 1983, 1985; $\mathrm{Cz}$ a p s ki and S a n i e w s ki, 1985). JA-Me stimulates chlorophyll degradation in 
mature green tomato fruit and this effect is not associated with the induction of polygalacturonase activity, development of which is inhibited by JA-Me in ripening tomatoes (S a n i e w s k i et al.,1987 c). Also in tomato fruits, JA-Me stimulates polyphenol oxidase and inhibits peroxidase activities ( $\mathrm{C} \mathrm{z}$ a p s k i and $\mathrm{S}$ a n i e ws k i, 1988), decreases tocopherol content ( $\mathrm{C} \mathrm{z}$ a p s k i et al.,1991), and greatly increases linolenic acid content ( $\mathrm{C} \mathrm{z}$ a p s k i et al., 1992).

Aminooxyacetic acid, an inhibitor of 1-aminocyclopropane-1-carboxylic acid (ACC) synthase, inhibited ethylene production stimulated by methyl jasmonate in normal ripening red tomatoes ( $\mathrm{S}$ a n i e w s k i and $\mathrm{C} \mathrm{z}$ a p s k i, 1990). It is well known that the common red tomato contains mainly lycopene with minor quantities of $\beta$ - and ( $\gamma$-carotene. A dominant gene T plays an important role in the formation of tomato pigments. RT phenotypic tomatoes biosynthesize mainly translycopene and $\mathrm{rT}$ phenotypic tomatoes form trans- $\beta$-carotene, accordingly the fruit colour is red and yellow respectively ( $\mathrm{J} \mathrm{o} \mathrm{h} \mathrm{j} \mathrm{i} \mathrm{m} \mathrm{a,} \mathrm{1993).} \mathrm{JA-Me} \mathrm{enhances} \mathrm{ethylene} \mathrm{production} \mathrm{in}$ normal red fruited tomatoes by its stimulatory effect on the turnover of ACC (S an i e w s k i et al., 1987 a, b). Also methyl jasmonate evidently stimulated ethylene production and ACC oxidase activity in fruits of the non-ripening tomato mutants, more efficiently in the nor than in the rin mutant $(\mathrm{C} \mathrm{z}$ a p s k i and $\mathrm{S}$ a $\mathrm{n}$ i e w s k i, 1992). The nor mutant gene is a part of chromosome 10 and affects colour changes and softening in a similar but less severe way than the rin gene. In both cases the respiratory climacteric is lacking and only $5-12 \%$ of normal ethylene production occurs (T i g c he la a r et al., 1978).

Since stimulation of ethylene biosynthesis responses to JA-Me of red fruited tomato also were exhibited by the nor and rin tomato mutants, therefore we examined the consequences of JA-Me application on yellowish-tangerine tomatoes. Due to our current interest in the effects of exogenously applied JA-Me on ethylene turnover in tomato fruits of different genotypes, the objective of this study was to determine the effect of JA-Me at different concentrations in lanolin paste on the ethylene producton, ACC oxidase activity and carbon dioxide evolution in tomato fruit of yellowish-tangerine cultivar.

\section{MATERIALS AND METHODS}

Plants of yellowish-tangerine tomatoes (cv. Bursztyn) were grown commercially in open in 1994. Tomato fruits were allowed to mature on the plants and they were harvested in August. Fruits were weighed and classified to three different stages of ripening: mature green, light yellow and yellow.

Five fruits were treated with $( \pm)$ methyl jasmonate at a concentrations of $0.1 \%$ and $1.0 \%$ in lanolin paste (prepared by mixing lanolin with $1 / 3$ part of distilled water). This was applied on the surface of individual intact fruit. Lanolin paste without JA-Me was used as a control. Fruits were kept at about $20^{\circ} \mathrm{C}$ under natural light condition. Four, 6 and 2 days after treatment for green, light yellow and yellow fruits respectively, skin with $2 \mathrm{~mm}$ pericarp tissue was cut off from an area of about $2 \mathrm{~cm}^{2}$. 
Slices ranging $150-200 \mathrm{mg}$ were placed in $10 \mathrm{ml}$ glass vials, $100 \mu \mathrm{l}$ of water (control) or $100 \mu \mathrm{l}$ of $1 \mathrm{mM}$ ACC were applied on the cut surface of the slices; the vials were then sealed tightly. After $2 \mathrm{~h}$ of incubation $1 \mathrm{ml}$ gas samples were withdrawn from the vials and ethylene and $\mathrm{CO}_{2}$ contents were determined. ACC oxidase activity was determined through ethylene production by slices treated with ACC. Ethylene was determined using gas chromatography method and $\mathrm{CO}_{2}$ was analyzed using infrared ADC gas analyzer. Each experiment was repeated at least three times. Data were tested by analysis of variance and evaluated using Newman-Keuls test at $\mathrm{P}=5 \%$ level of significance.

\section{RESULTS AND DISCUSSION}

The yellowish-tangerine tomato (cv. Bursztyn) in the green, light yellow and yellow stages of ripening were treated with $0.1 \%$ and $1.0 \%$ of methyl jasmonate (JA-Me) in lanolin paste and kept for several days. Green fruits after treatment with $0.1 \%$ of JA-Me did not change in colour and $1.0 \%$ of JA-Me turned their color into light yellow during 4 days. Light yellow fruits treated with both concentrations of JA-Me turned into yellow. Production of endogenous ethylene in green tomato was the lowest (Fig.1). The application of JA-Me to tomatoes stimulated ethylene production in all investigated stages of fruit ripening. The highest level of ethylene production after JA-Me treatment was found in yellow (most ripen) stage of the yellowish-tangerine tomato fruit, although the highest stimulation of ethylene production for green fruits was observed. Ethylene production by $0.1 \% \mathrm{JA}-\mathrm{Me}$ was 11.0 , 3.8 and 5.6 fold higher in the green, light yellow and yellow fruits, respectively, as compared with appriopriate controls (Fig.1).

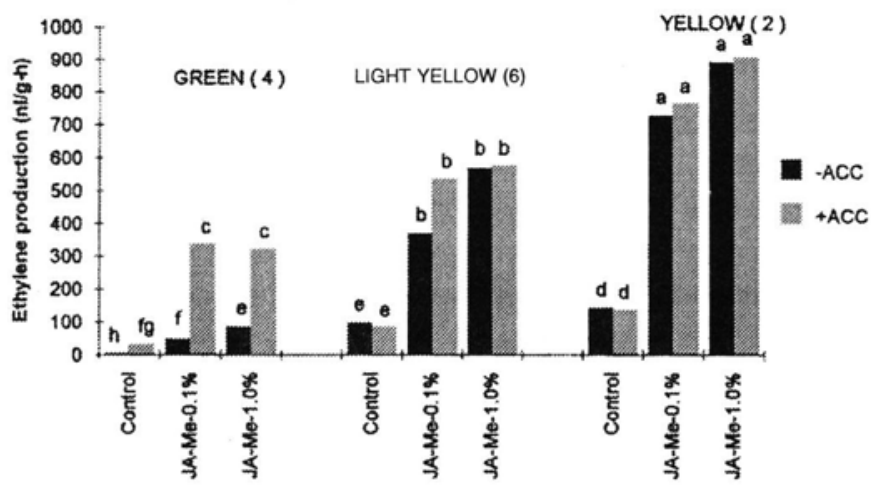

Fig. 1. The effect of methyl jasmonate (JA-Me) applied to tomato fruits at different stages of ripening on ethylene production in slices

Notes: "GREEN", "LIGHT YELLOW" and "YELLOW" describes color of fruits before treament Numbers in brackets: number of days from treatment to analysis. Colour of treated skin area of green fruits after 4 days of treatment: Control - green JA-Me- $0.1 \%$ - green, JA-Me- $1.0 \%$ - light yellow. [- ACC] - Endogenous ethylene: $[+\mathrm{ACC}]-$ Ethylene production after ACC treatment. Means followed by the same letter do not differ at the $5 \%$ level of signifi-cance for all stages of ripening. 
Application of ACC to control slices excised from green tomatoes increased production of ethylene (Fig. 1). However, application of ACC to slices excised from $\mathrm{JA}-\mathrm{Me}(0.1 \%$ and $1.0 \%)$ treated green tomatoes increased a few times ethylene production in comparison to control slices (Fig. 1). High activity of the ACC oxidase in JA-Me treated slices from green fruit suggests that the production of endogenous ACC is the limiting factor for ethylene biosynthesis in this fruit.

An application of ACC to slices excised from control and JA-Me treated fruits in light yellow and yellow stages of ripening did not stimulate ethylene production, since the endogenous level of ACC was sufficient and ethylene production was limited by ACC oxidase activity. It was observed in ripe and overripe normal red tomatoes ( $\mathrm{H} \mathrm{o} \mathrm{f} \mathrm{f} \mathrm{m} \mathrm{a} \mathrm{n}$ and Y a $\mathrm{ng}, 1980$ ). Strong stimulatory effect of JA-Me on ethylene production in light yellow and yellow stages of yellowish-tangerine tomatoes is caused by increased activity of ACC oxidase. The stimulatory effect of JA-Me on ACC oxidase activity and ethylene production was previously well documented in normal ripening red fruits and in non ripening nor and rin tomato mutants (S a n i e w s ki et al., 1987 b; C z a p ski and S a n i ew ski, 1992).

L e e and H w a (1995) showed different effect of methyl jasmonate on ethylene production in fruit and hypocotyl segments of tomato. In hypocotyl segments JA-Me showed $50 \%$ of inhibitory effect of ethylene production after $3 \mathrm{~h}$ of incubation period. Such inhibitory effect was due to the decrease in ACC synthase activity but not due to ACC oxidase activity. In contrast, when tomato fruits were treated $\mathrm{JA}-\mathrm{Me}$ in gaseous state, ethylene production increased double and continued until 4 days. It was due to increase the activities both of ACC synthase and ACC oxidase, and induced ACC oxidase mRNA accumulation in fruit tissue. These data suggest that JA-Me plays distinct role in ethylene production in different tomato tissues. It may be possible that JA-Me affects differently the mechanisms of signal transduction leading to the ethylene biosynthesis ( $\mathrm{L} \mathrm{e} \mathrm{e} \mathrm{and} \mathrm{H}$ w a, 1995). These findings were confirmed by $\mathrm{P}$ a r k et al. (1995). They showed that JA-Me inhibited auxin induced ethylene production in mungbean hypocotyls while it stimulated the ethylene production in detached leaves. It was found that auxin-induced ACC accumulation decreased by JA-Me in hypocotyls, but not in leaves and ACC oxidase activity was inhibited in hypocotyls while it was greatly stimulated in leaves. Investigation of expression of genes encoding ACC synthase and ACC oxidase led authors to conclusion that the JA-Me effects are primarily on the gene expression involved in ethylene biosynthesis.

Slices excised from green fruits produced the highest amount of carbon dioxide as compared to those from more than green advanced stages of ripening (Fig.2). JA-Me significantly stimulated $\mathrm{CO}_{2}$ production in green fruits, although there was no difference between $0.1 \%$ and $1.0 \% \mathrm{JA}-\mathrm{Me}$. Considering fruits treated in light yellow and yellow stages of ripening, stimulation by $1.0 \% \mathrm{JA}-\mathrm{Me}$ can be observed only. The application of ACC did not change $\mathrm{CO}_{2}$ evolution (Fig. 2). Recently, S a n i e w s ki and Węgrz y n ow i c z-Les i a k (1995) showed that spraying of intact Kalanchoe blossfeldiana with methyl jasmonate induced the abscission of 
leaves during 2-3 days and evidently increased $\mathrm{CO}_{2}$ evolution. However, $\mathrm{U}$ e d a et al. (1994) found that jasmonic acid did not affect the rate of oxygen consumption by oat coleoptile segments in the presence or absence of IAA.

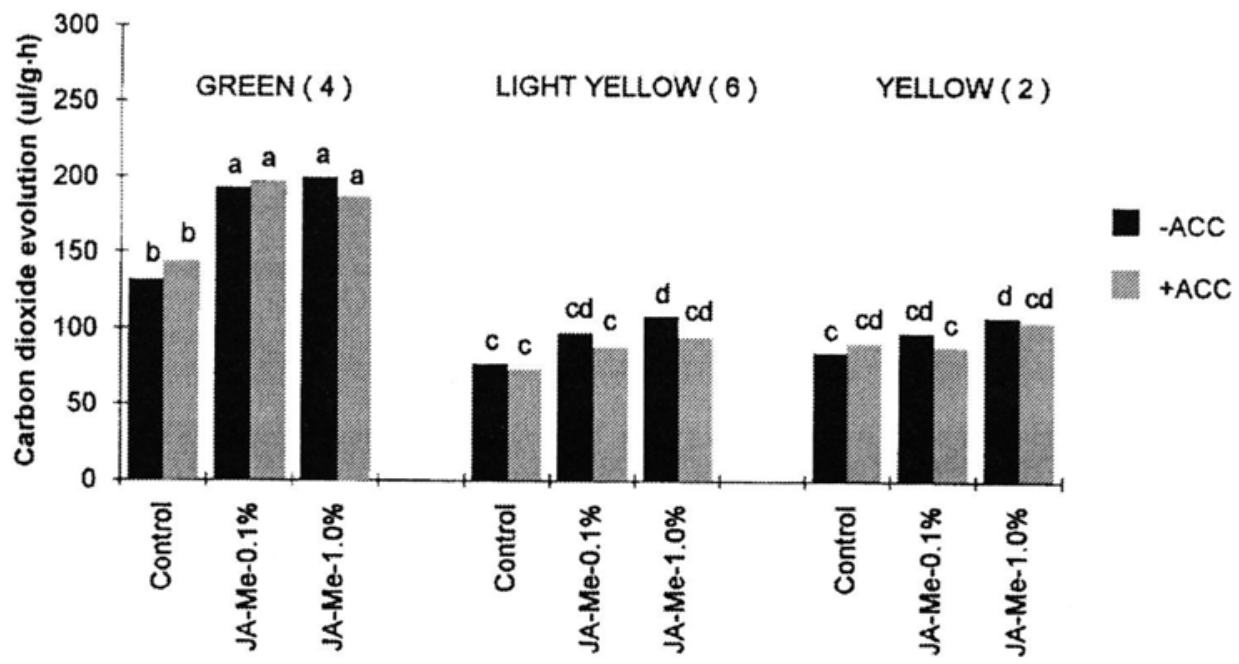

Fig. 2. The effect of methyl jasmonate (JA-Me) applied to tomato fruits at different stages of ripening on $\mathrm{CO}_{2}$ evolution in slices. Notes - see Fig. 1.

Acknowledgements: We wish to thank Dr. E. D e m o l e, Firmenich S.A., Geneva, Switzerland for the gift of authentic $( \pm)$ - methyl jasmonate.

\section{REFERENCES}

C z a p s k i J., Horbowi c z M., S a n i ew ski M., 1991. The effect of methyl jasmonate on tocopherols content in ripening tomato fruit. Bull. Pol. Ac.: Biol. 39: 41-45.

C z a p s k i J., Horbow i c z M., S a n i e w s k i M., 1992. The effect of methyl jasmonate on free fatty acids content in ripening tomato fruits. Biol. Plant. 34: 71-76.

C z a p s k i J., S a n i e w s k i M., 1985. Effect of methyl jasmonate on carotenoids in tomato fruits. Gartenbauwiss. 50: 35-37.

C z a p s k i J., S a n i e w s k i M., 1988. The effect of methyl jasmonate on polyphenol oxidase and peroxidase activities in tomato fruit. Bull. Pol. Ac.: Biol. 39: 41-45.

C z a p s k i J., S a n i e w s k i M., 1992. Stimulation of ethylene production and ethylene - forming en zyme activity in fruits of the non-ripening nor and rin tomato mutants by methyl jasmonate. J. Plant Physiol. 139: 265-268.

$\mathrm{H}$ of $\mathrm{f} \mathrm{m}$ a $\mathrm{n} \mathrm{N}$. E., Y a $\mathrm{n} g$ S. F., 1980. Changes of 1-amino-cyclopropane-1-carboxylic acid content in ripening fruits in relation to their ethylene production rates. J. Amer. Soc. Hort. Sci. 105: 492-495.

$\mathrm{J} \mathrm{o} \mathrm{h} \mathrm{j} \mathrm{i} \mathrm{m} \mathrm{a} \mathrm{T.,} \mathrm{1993.} \mathrm{Determination} \mathrm{of} \mathrm{cis} \mathrm{and} \mathrm{trans} \mathrm{carotenes} \mathrm{of} \mathrm{tangerine} \mathrm{and} \mathrm{yellowish} \mathrm{tangerine} \mathrm{tomatoes}$ by micro-thin-layer chromatography. J. Japan. Soc. Hort. Sci. 62: 567-574.

L e e J. S., H w a J. J., 1995. Effect of methyl jasmonate on ethylene production in tomato hypocotyl segments and fruits. 15th Intern. Conference on Plant Growth Substances, July 14-18, 1995, Minneapolis, Minnesota, USA, Program-Abstracts, Abstract No. 267.

Me ye r A., M i e r s h O., B t t t n e r C., D a the W., S e m b d n e r G., 1984. Occurrence of the plant growth regulator jasmonic acid in plants . J. Plant Growth Regul. 3: 1-8. 
Park D. H., Kong E. W., Y o on I. S., K i m W. T., Le e J. S., K a n g B. G., 1995. Effects of methyl jasmonate on ethylene biosynthesis in mungbean. 15th Intern. Conference on Plant Growth Substances, July 14-18, 1995, Minneapolis, Minnesota, USA, Program-Abstracts, Abstract No. 469.

S a n i e w s k i M., C z a p s k i J., 1983. The effect of methyl jasmonate on lycopene and $\beta$-carotene accumulation in ripening red tomatoes. Experientia, 39: 1373-1374.

S a n i e w sk i M., C z a p s k i J., 1985. Stimulatory effect of methyl jasmonate on ethylene pro-duction in tomato fruits. Experientia, 41: 256-257.

S a n i e w sk i M., C z a p sk i J., 1990. The effect of aminooxyacetic acid on ethylene production induced by methyl jasmonate in tomatoes. Biol. Plant. 32: 218-222.

S a n i e w ski M., C z a p ski J., N ow a ck i J., 1987 a. Relationship between stimulatory effect of methyl jasmonate on ethylene and 1-aminocyclopropane-1-carboxylic acid content in tomatoes. Biol. Plant. 29: 17-21.

S a niewski M., N ow a c k i J., C z a p s k i J., 1987 b. The effect of methyl jasmonate on ethylene production and ethylene forming enzyme activity in tomatoes. J. Plant Physiol. 129: 175-180.

Saniewski M., U rb a n e k H., C z a p s k i J., 1987 c. Effects of methyl jasmonate on ethylene production, chlorophyll degradation, and polygalacturonase activity in tomatoes. J. Plant Physiol. 127: 177-181.

S a n i e w ski M., Węgrzy n ow i c z - Les i a k E., 1995. Methyl jasmonate-induced leaf abscission in Kalanchoe blossfeldiana. Acta Hortic. 394: 315-324.

T i g che la ar E. C., M c Glas s on W. B., B ues cher R. W., 1978. Genetic regulation of tomato fruit ripening. Hort Science 13: 508-513.

U e d a J., M i y a m o to K., A o k i M., 1994. Jasmonic acid inhibits the IAA - induced elongation of oat coleoptile segments: a possible mechanism involving the metabolism of cell wall polysaccharides. Plant Cell Physiol. 35: 1065-1070.

\title{
Wpływ estru metylowego kwasu jasmonowego na produkcję etylenu, aktywność oksydazy ACC i wydzielanie dwutlenku węgla w owocach żółto-pomarańczowej odmiany pomidorów
}

\author{
Streszczen i e
}

Produkcja endogennego etylenu w wyrośniętych zielonych pomidorach odmiany żótto-pomarańczowej Bursztyn była niska i wzrastała w miarę ich dojrzewania. Ester metylowy kwasu jasmonowego (JA-Me) zwiększał zarówno produkcję etylenu jak i aktywność oksydazy ACC we wszystkich stadiach dojrzałości owoców. Wycinki z owoców zielonych wydzielały istotnie więcej dwutlenku węgla niż wycinki pobrane z owoców bardziej dojrzałych. JA-Me w stężeniach $0.1 \%$ i $1.0 \%$ zwiększał wydzielanie $\mathrm{CO}_{2}$ w wycinkach owoców zielonych, natomiast w owocach bardziej dojrzałych tylko stężenie $1.0 \%$ JA-Me powodowalo nieznaczny wzrost produkcji dwutlenku węgla. 